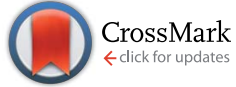

Cite this: RSC Adv., 2016, 6, 16150

Received 14th January 2016

Accepted 1st February 2016

DOI: 10.1039/c6ra01131d

www.rsc.org/advances

\section{Dye-sensitized solar cell based on an inclusion complex of a cyclic porphyrin dimer bearing four 4- pyridyl groups and fullerene $\mathrm{C}_{60}{ }^{\dagger}$}

\author{
Yousuke Ooyama, ${ }^{\star a}$ Koji Uenaka, ${ }^{a}$ Takuya Kamimura, ${ }^{\mathrm{b}}$ Shuwa Ozako, \\ Masahiro Kanda, ${ }^{a}$ Taro Koide ${ }^{b}$ and Fumito Tani ${ }^{\star b}$
}

Cyclic free-base porphyrin dimers $\left(\mathrm{H}_{4}-\mathrm{C}_{4}-\mathrm{CPD}_{\mathrm{Py}}(\mathrm{TEO})\right.$ and $\left.\mathrm{H}_{4}-\mathrm{Ptz}-\mathrm{CPD}_{\mathrm{Py}}(\mathrm{TEO})\right)$ linked by butadiyne or phenothiazine bearing four 4-pyridyl groups and their inclusion complexes $\left(\mathrm{C}_{60} \subset \mathrm{H}_{4}-\mathrm{C}_{4}-\mathrm{CPD}_{\mathrm{Py}}\right.$ (TEO) and $\mathrm{C}_{60} \subset \mathrm{H}_{4}-\mathrm{Ptz}-\mathrm{CPD}_{\mathrm{Py}}(\mathrm{TEO})$ ) with fullerene $\mathrm{C}_{60}$ have been applied to dye-sensitized solar cells (DSSCs) as a new class of porphyrin dye sensitizers with pyridyl anchoring groups for attachment on a $\mathrm{TiO}_{2}$ electrode. The FTIR spectra of the porphyrin dimers adsorbed on $\mathrm{TiO}_{2}$ nanoparticles demonstrated that these porphyrin dimers are adsorbed on the $\mathrm{TiO}_{2}$ surface through the formation of hydrogen bonding of pyridyl groups and/or pyridinium ions at Brønsted acid sites on the $\mathrm{TiO}_{2}$ surface. The adsorption amount of the porphyrin dimers adsorbed on the $\mathrm{TiO}_{2}$ electrode is $2.0 \times 10^{17}$ molecules per $\mathrm{cm}^{2}$, that is, the adsorption amount of the porphyrin unit is $4.0 \times 10^{17} \mathrm{~cm}^{-2}$, which is higher than that of dye sensitizers with pyridyl groups reported so far. The photovoltaic performance of DSSCs based on phenothiazinebridged cyclic porphyrin dimer $\mathrm{H}_{4}$-Ptz-CPD $\mathrm{Py}_{\mathrm{P}}(\mathrm{TEO})$ is higher than that of DSSCs based on butadiynelinked cyclic porphyrin dimer $\mathrm{H}_{4}-\mathrm{C}_{4}-\mathrm{CPD}_{\mathrm{Py}}(\mathrm{TEO})$. Moreover, the photovoltaic performances of DSSCS based on cyclic free-base porphyrin dimers are higher than those of DSSCs based on their $\mathrm{C}_{60}$ inclusion complexes $\mathrm{C}_{60} \subset \mathrm{H}_{4}-\mathrm{C}_{4}-\mathrm{CPD}_{\mathrm{Py}}(\mathrm{TEO})$ and $\mathrm{C}_{60} \subset \mathrm{H}_{4}-\mathrm{Ptz}_{-\mathrm{CPD}}$ (TEO). On the basis of the electrochemical measurements (voltammetry and electrochemical impedance spectroscopy) and the transient absorption spectroscopy, the differences in the photovoltaic performances among these cyclic free-base porphyrin dimers are discussed from kinetic and thermodynamic considerations concerning the electron transfer processes in DSSCs.

\section{Introduction}

Dye-sensitized solar cells (DSSCs) employing dye-adsorbed $\mathrm{TiO}_{2}$ electrodes are one of the most promising new renewable photovoltaic cells utilizing the sun as a free and inexhaustible energy source because of their interesting construction and operational principles, and low cost of production, since Grätzel and co-workers produced high-performance DSSCs based on a Ru-complex dye, which showed a solar energy-to-electricity conversion yield $(\eta)$ of $11 \%{ }^{1}$ To further improve the photovoltaic performance of DSSCs, many kinds of ruthenium (Ru) dyes, porphyrin dyes, phthalocyanine dyes and organic dyes bearing carboxyl groups as anchoring groups, which are adsorbed on

${ }^{a}$ Department of Applied Chemistry, Graduate School of Engineering, Hiroshima University, Higashi-Hiroshima 739-8527, Japan. E-mail: yooyama@hiroshima-u.ac. jp; Fax: +81-82-424-5494

${ }^{b}$ Institute for Materials Chemistry and Engineering, Kyushu University, 744 Motooka, Nishi-ku, Fukuoka 819-0395, Japan. E-mail: tanif@ms.ifoc.kyushu-u.ac.jp; Fax: +8192-802-6224

$\dagger$ Electronic supplementary information (ESI) available: ${ }^{1} \mathrm{H}$ NMR and ${ }^{13} \mathrm{C}$ NMR for compounds 1, 2 and $\mathbf{H}_{4}-\mathbf{C}_{4}-\mathbf{C P D}_{\mathbf{P y}}$ (TEO). See DOI: 10.1039/c6ra01131d the $\mathrm{TiO}_{2}$ electrode through the bidentate bridging linkage between the carboxyl group of the dye and Brønsted acid sites (surface-bound hydroxyl groups, Ti-OH) on the $\mathrm{TiO}_{2}$ surface, have been developed as dye sensitizers during the last two decades. ${ }^{2-9}$ In particular, porphyrin dyes have been regarded as promising candidates for photosensitizers as a result of their strong Soret (400-500 nm) and moderate Q band (500-700 nm) absorption properties, as well as their electrochemical, photochemical and thermal stabilities. Much effort in molecular design and development of porphyrin dye sensitizers having carboxyl group have been made to further improve the photovoltaic performances of DSSCs so far. ${ }^{\mathbf{1 0 - 1 5}}$ Consequently, DSSCs based on donor- $\pi$-acceptor $(\mathrm{D}-\pi-\mathrm{A})$ porphyrin dyes bearing the diarylamino group as an electron donor and the benzothiadiazole-benzoic acid moiety as an electron acceptor, which exhibited good absorption features (bathochromic shift and broadening of the Soret and $\mathrm{Q}$ bands), have achieved $\eta$ value of up to $c a .13 \% .^{11 d, e}$

On the other hand, we have reported that a new type of $D-\pi-$ A dye sensitizers bearing pyridyl group as electron-withdrawing anchoring group were predominantly adsorbed on the $\mathrm{TiO}_{2}$ electrode through coordinate bonding between the pyridyl 
group of the dye and the Lewis acid site (exposed $\mathrm{Ti}^{n+}$ cations) on the $\mathrm{TiO}_{2}$ surface. ${ }^{16,17}$ It was demonstrated that the new-type of $\mathrm{D}-\pi-\mathrm{A}$ dye sensitizers can inject electrons efficiently from the pyridyl group to the conduction band (CB) of the $\mathrm{TiO}_{2}$ electrode through the coordinate bonding, rather than the bidentate bridging linkages of conventional $\mathrm{D}-\pi-\mathrm{A}$ dye sensitizers bearing carboxyl group. Recently, Wang et al. reported that DSSCs based on D- $\pi-\mathrm{A}$ porphyrin dye bearing a pyridyl group reached solar energy-to-electricity conversion yield $(\eta)$ of $3.96 \% .{ }^{18 a}$ On the other hand, Goutsolelos et al. reported the $\eta$ value of $3.9 \%$ for DSSC based on porphyrin dye bearing four pyridyl groups. ${ }^{18 c}$ However, the adsorption amounts $(<5.0 \times$ $10^{16}$ molecules per $\mathrm{cm}^{2}$ ) of these porphyrin dye sensitizers bearing pyridyl group adsorbed on $\mathrm{TiO}_{2}$ electrode are much lower than those of porphyrin dye sensitizers bearing carboxyl group, and thus the low dye loading leads to low lightharvesting efficiency (LHE) and poor surface coverage of the $\mathrm{TiO}_{2}$ electrode, resulting in lowering of the photovoltaic performances of DSSCs. ${ }^{\mathbf{1 8 , 1 9}}$ More recently, Goutsolelos et al. have designed and synthesized "spider-shaped" porphyrin dye sensitizer bearing oligophenylenevinylene moieties, long dodecyloxy chains, and four pyridyl groups, which showed high dye loading value $\left(1.9 \times 10^{17}\right.$ molecules per $\left.\mathrm{cm}^{2}\right)$ due to an increase in the basicity of the pyridyl groups. As the results, the DSSC based on the "spider-shaped" porphyrin dye sensitizer reached the $\eta$ value of $5.12 \% .^{18 e}$

Recently, we have designed and prepared cyclic free-base porphyrin dimers $\left(\mathbf{H}_{\mathbf{4}}-\mathbf{C}_{\mathbf{4}}-\mathbf{C P D}_{\mathbf{P y}}\right.$ (TEO) and $\mathbf{H}_{\mathbf{4}}$-Ptz-CPD $\mathbf{P D}_{\mathbf{P y}}$ (TEO)) linked by butadiyne or phenothiazine bearing four 4-pyridyl groups and their inclusion complexes $\left(\mathbf{C}_{60} \subset \mathbf{H}_{4}-\mathbf{C}_{4}-\mathbf{C P D}_{\mathbf{P y}}\right.$ (TEO) and $\mathbf{C}_{60} \subset \mathbf{H}_{4}$-Ptz-CPD ${ }_{\mathbf{P y}}($ TEO) $)$ with fullerene $\mathrm{C}_{60} \cdot{ }^{20}$ It was found that these porphyrin dimers have favorable photochemical and electrochemical properties for DSSC through the electrochemical measurements and the transient absorption spectroscopy. Moreover, as for phenothiazine derivative $\mathbf{H}_{\mathbf{4}} \mathbf{- P t z}$ $\mathbf{C P D}_{\mathbf{P y}}$ (TEO), it would be expected that the phenothiazine unit possessing electron donating ability can provide a unidirectional flow of electrons toward the pyridyl anchoring group upon photoexcitation of the porphyrin, leading to the efficient electron injection from the photoexcited dye to the $\mathrm{CB}$ of $\mathrm{TiO}_{2}$ electrode. Thus, in this work, to achieve high dye loading and high surface coverage of the $\mathrm{TiO}_{2}$ electrode for DSSCs based on porphyrin dye sensitizers bearing pyridyl group, the cyclic free-
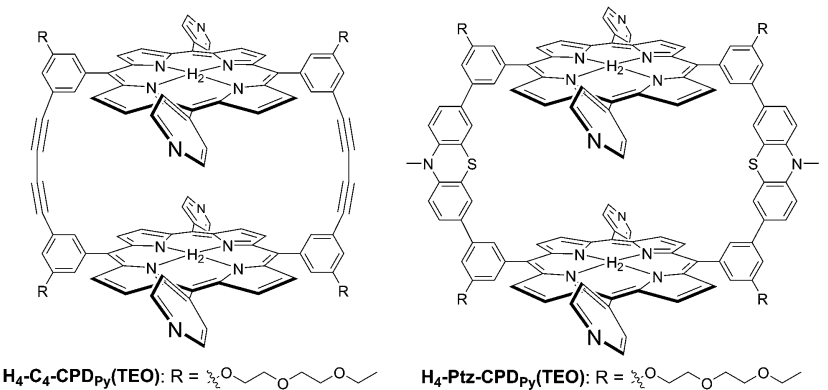

$\mathrm{H}_{4}-\mathrm{C}_{4}-\mathrm{CPD}_{\mathrm{Py}}(\mathrm{TEO}): \mathrm{R}=\mathrm{s}_{2} \mathrm{O} \sim \mathrm{O} \sim \mathrm{O}$

Scheme 1 Cyclic free-base porphyrin dimers $\left(\mathrm{H}_{4}-\mathrm{C}_{4}-\mathrm{CPD}_{\mathrm{Py}}(\mathrm{TEO})\right.$ and $\mathrm{H}_{4}-$ Ptz-CPD $\left._{\mathrm{Py}}(\mathrm{TEO})\right)$ bearing 4-pyridyl groups. base porphyrin dimers $\mathbf{H}_{\mathbf{4}}-\mathbf{C}_{\mathbf{4}}-\mathbf{C P D}_{\mathbf{P y}}(\mathbf{T E O})$ and $\mathbf{H}_{\mathbf{4}}-\mathbf{P t z}-\mathbf{C P D}_{\mathbf{P y}^{-}}$ (TEO) and their $\mathrm{C}_{60}$ inclusion complexes $\mathbf{C}_{60} \subset \mathbf{H}_{4}-\mathbf{C}_{4}-\mathbf{C P D}_{\mathbf{P y}^{-}}$

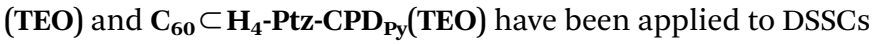
as a new class of porphyrin dye sensitizers bearing pyridyl anchoring groups for attachment on $\mathrm{TiO}_{2}$ electrode (Scheme 1). It was demonstrated that these porphyrin dimers are adsorbed on the $\mathrm{TiO}_{2}$ surface through the formations of hydrogen bonding of pyridyl groups and/or pyridinium ion at Brønsted acid sites on the $\mathrm{TiO}_{2}$ surface. Here we reveal the photovoltaic performances of DSSCs based on these porphyrin dimers from kinetic and thermodynamic consideration concerning the electron transfer processes in DSSCs, based on the electrochemical measurements (voltammetry and electrochemical impedance spectroscopy) and the transient absorption spectroscopy.

\section{Results and discussion}

Photoabsorption properties of cyclic free-base porphyrin dimers and their inclusion complexes with fullerene $\mathbf{C}_{60}$

The synthesis of $\mathbf{H}_{\mathbf{4}}$-Ptz-CPD $\mathbf{P y}$ (TEO) has been reported elsewhere. ${ }^{20 e}$ The synthetic pathway for $\mathbf{H}_{4}-\mathbf{C}_{4}-\mathbf{C P D}_{\mathbf{P y}}(\mathbf{T E O})$ is shown in Scheme 2. The inclusion complexes $\mathbf{C}_{60} \subset \mathbf{H}_{4}-\mathbf{C}_{\mathbf{4}}-\mathbf{C P D}_{\mathbf{P y}}$ (TEO) and $\mathbf{C}_{60} \subset \mathbf{H}_{4}$-Ptz-CPD $\mathbf{P y}_{\mathbf{P y}}$ (TEO) with $\mathrm{C}_{60}$ were prepared by slowly evaporating the mixed solution of the corresponding cyclic freebase porphyrin dimer in chloroform $(0.1 \mathrm{mM}, 5 \mathrm{~mL})$ and $\mathrm{C}_{60}$ in toluene $(0.1 \mathrm{mM}, 5 \mathrm{~mL})$. The UV/vis absorption spectra of cyclic free-base porphyrin dimers $\mathbf{H}_{4}-\mathbf{C}_{4}-\mathbf{C P D}_{\mathbf{P y}}(\mathbf{T E O})$ and $\mathbf{H}_{4}-\mathbf{C}_{\mathbf{4}}$ $\mathbf{C P D}_{\mathbf{P y}}$ (TEO) in benzonitrile are shown in Fig. 1 and their spectral data are summarized in Table 1 . The porphyrin dimers $\mathbf{H}_{\mathbf{4}}-\mathbf{C}_{\mathbf{4}}-\mathbf{C P D}_{\mathbf{P y}}$ (TEO) and $\mathbf{H}_{\mathbf{4}}$-Ptz-CPD $\mathbf{P y}_{\mathbf{P}}$ (TEO) exhibit strong soret band at around $420 \mathrm{~nm}$ and relatively weak $\mathrm{Q}$ band in the range 500-650 nm. For the $\mathrm{C}_{60}$ inclusion complexes $\mathbf{C}_{60} \subset \mathbf{H}_{4}-\mathbf{C}_{\mathbf{4}^{-}}$

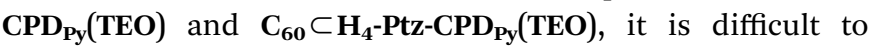

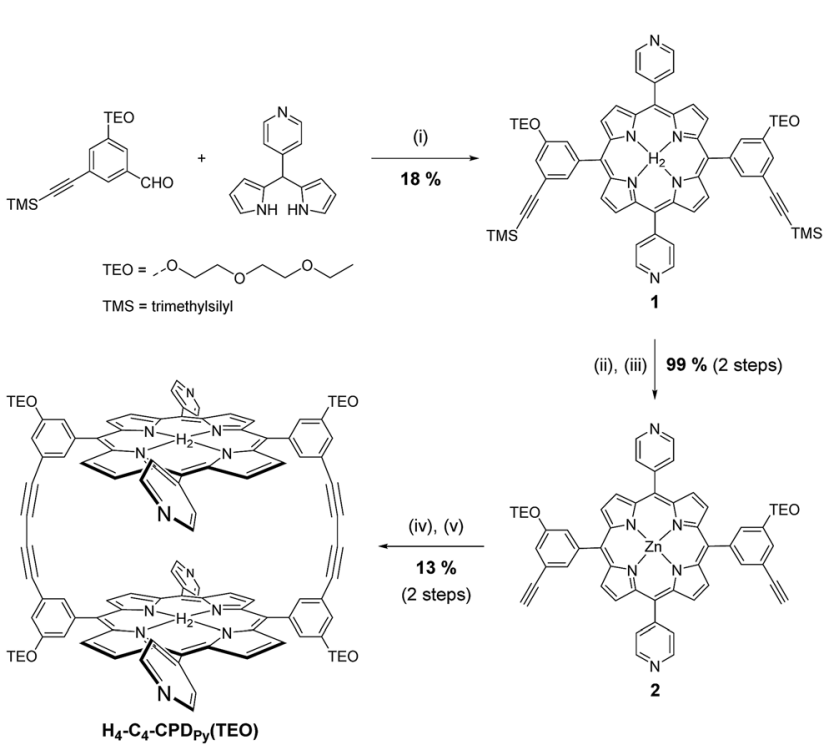

Scheme 2 Synthetic pathway for $\mathrm{H}_{4}-\mathrm{C}_{4}-\mathrm{CPD}_{\mathrm{Py}}(\mathrm{TEO})$. (i) TFA, DDQ, $\mathrm{CH}_{2} \mathrm{Cl}_{2}$; (ii) $\mathrm{Zn}(\mathrm{OAC}) \cdot 2 \mathrm{H}_{2} \mathrm{O}, \mathrm{MeOH}, \mathrm{CH}_{2} \mathrm{Cl}_{2}$; (iii) $\mathrm{KF}, \mathrm{DMF}$; (iv) $\mathrm{CuCl}$, pyridine, air; (v) $\mathrm{HCl}$ aq. 


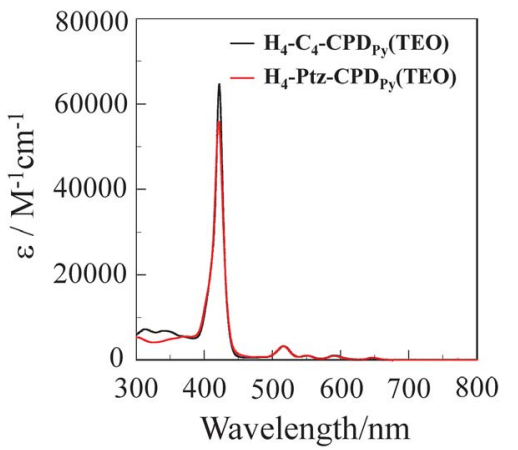

Fig. 1 UV/vis absorption spectra of $\mathrm{H}_{4}-\mathrm{C}_{4}-\mathrm{CPD}_{\mathrm{Py}}(\mathrm{TEO})$ and $\mathrm{H}_{4}-\mathrm{Ptz}-$ $\mathrm{CPD}_{\mathrm{Py}}(\mathrm{TEO})$ in benzonitrile.

obtain their exact absorption spectra because the $1: 1$ complex of $\mathbf{H}_{4}-\mathbf{C}_{\mathbf{4}}-\mathbf{C P D}_{\mathbf{P y}}$ (TEO) or $\mathbf{H}_{\mathbf{4}}$-Ptz-CPD $\mathbf{P y}$ (TEO) with $\mathrm{C}_{60}$ is in dissociation equilibrium in solution of $10^{-5}$ to $10^{-6} \mathrm{M}$ concentration which is suitable for the measurement of absorption spectra of porphyrins. In our previous work, however, we have demonstrated that upon addition of $\mathrm{C}_{60}$ to the benzonitrile solution of the cyclic porphyrin dimers, their Soret bands were redshifted with a decrease in intensity, whereas their Q bands were slightly redshifted but increased in intensity. ${ }^{\mathbf{2 0}}$

The UV/vis absorption spectra of cyclic free-base porphyrin dimers and their $\mathrm{C}_{60}$ inclusion complexes adsorbed on $\mathrm{TiO}_{2}$ film are shown in Fig. 2. It is worth mentioning here that the adsorption amount of the porphyrin dimers adsorbed on $\mathrm{TiO}_{2}$ film is $2.0 \times 10^{17}$ molecules per $\mathrm{cm}^{2}$, that is, the adsorption amount of porphyrin unit is $4.0 \times 10^{17} \mathrm{~cm}^{-2}$, which is higher than those $\left(<2.0 \times 10^{17}\right.$ molecules per $\left.\mathrm{cm}^{2}\right)$ of porphyrin dye sensitizers and $\mathrm{D}-\pi-\mathrm{A}$ dye sensitizer bearing pyridyl groups reported so far. ${ }^{16,18}$ The Soret bands of $\mathbf{C}_{60} \subset \mathbf{H}_{4}-\mathbf{C}_{4}-\mathbf{C P D}_{\mathbf{P y}}$ (TEO) and $\mathbf{C}_{60} \subset \mathbf{H}_{4}$-Ptz-CPD $\mathbf{P y}_{\mathbf{P y}}$ (TEO) were redshifted compared to those of $\mathbf{H}_{4}-\mathbf{C}_{4}-\mathbf{C P D}_{\mathbf{P y}}$ (TEO) and $\mathbf{H}_{4}-\mathbf{P t z}-\mathbf{C P D}_{\mathbf{P y}}(\mathbf{T E O})$, although there is little difference in the $\mathrm{Q}$ band between the cyclic free-base porphyrin dimers and their $\mathrm{C}_{60}$ inclusion complexes. Thus, the UV/vis absorption spectra of these porphyrin dimers-adsorbed $\mathrm{TiO}_{2}$ films are in good agreement with those in benzonitrile.

\section{Electrochemical and photochemical properties of cyclic free- base porphyrin dimers and their inclusion complexes with fullerene $\mathbf{C}_{60}$}

The electrochemical properties of cyclic free-base porphyrin dimers and their $\mathrm{C}_{60}$ inclusion complexes were determined by cyclic voltammetry (CV) and differential pulse voltammetry (DPV) (see Fig. S7-S10 in ESI $\dagger$ ). ${ }^{20}$ The oxidation potential of the porphyrin unit in $\mathbf{C}_{60} \subset \mathbf{H}_{\mathbf{4}}-\mathbf{C}_{\mathbf{4}}-\mathbf{C P D} \mathbf{D P y}_{\mathbf{P y}}$ (TEO) $\left(0.74 \mathrm{~V}\right.$ vs. $\left.\mathrm{Fc} / \mathrm{Fc}^{+}\right)$ showed anodic shift by $0.03 \mathrm{~V}$, compared with that of $\mathbf{H}_{4}-\mathbf{C}_{4^{-}}$ CPD $_{\mathbf{P y}}$ (TEO) (0.71 V) (Table 1). The oxidation potential of the porphyrin unit in $\mathbf{C}_{60} \subset \mathbf{H}_{\mathbf{4}}$-Ptz-CPD $\mathbf{P D}_{\mathbf{P y}}$ (TEO) $(0.75 \mathrm{~V})$ also showed anodic shift by $0.03 \mathrm{~V}$, compared with that of $\mathbf{H}_{\mathbf{4}}-\mathbf{P t z}-\mathbf{C P D}_{\mathbf{P y}}$ (TEO) $(0.72 \mathrm{~V})$. The reduction potentials corresponding to the reduction of the fullerene entity of $\mathbf{C}_{60} \subset \mathbf{H}_{4}-\mathbf{C}_{4}$ - $\mathbf{C P D} \mathbf{P D y}_{\mathbf{P y}}$ (TEO) and $\mathbf{C}_{60} \subset \mathbf{H}_{4}$-Ptz-CPD $D_{\mathbf{P y}}(\mathbf{T E O})$ were observed at $-0.94 \mathrm{~V}$ and $-0.96 \mathrm{~V}$, respectively, which is cathodically shifted by $0.02 \mathrm{~V}$ and $0.04 \mathrm{~V}$, respectively, compared to pristine $\mathrm{C}_{60}(-0.92 \mathrm{~V}) .{ }^{20 e}$ The small anodic shift of the oxidation potential of the porphyrin and the small cathodic shift of the reduction potential of $\mathrm{C}_{60}$ compared with their reference compounds is indicative of the charge transfer interaction between the porphyrins and $\mathrm{C}_{60}$. The HOMO and LUMO energy levels were evaluated from the oxidation wave and the singlet excited energy of these porphyrin dimers $(1.90 \mathrm{eV})$ based on the $\mathrm{Q}$ absorption band and fluorescence band in benzonitrile (ca. $650 \mathrm{~nm}$ ), respectively. The HOMO and LUMO energy levels of these porphyrin dimers was ca. $-5.5 \mathrm{eV}$ and $c a$. $-3.6 \mathrm{eV}$, respectively (Table 1). Thus, this result shows that the HOMO energy levels are more positive than the $\mathrm{I}_{3}{ }^{-} / \mathrm{I}^{-}$redox potential $(-4.9 \mathrm{eV})$, and thus this indicates that an efficient regeneration of the oxidized porphyrin dimers by electron transfer from the $\mathrm{I}_{3}{ }^{-} / \mathrm{I}^{-}$redox couple in the electrolyte is thermodynamically feasible. Evidently, the LUMO energy levels of these porphyrin dimers are higher than the energy level $\left(E_{\mathrm{cb}}\right)$ of the $\mathrm{CB}$ of $\mathrm{TiO}_{2}(-4.0 \mathrm{eV})$, suggesting that an electron injection to the $\mathrm{CB}$ of $\mathrm{TiO}_{2}$ is thermodynamically feasible (some researchers have proposed that an energy gap of over $0.2-0.3 \mathrm{eV}$ is necessary for efficient electron injection). ${ }^{2-7}$

Time-resolved absorption spectroscopy for cyclic free-base porphyrin dimers and their $\mathrm{C}_{60}$ inclusion complexes was performed by femtosecond laser flash photolysis after photoexcitation. ${ }^{20}$ The photodynamics of these porphyrin dimers is summarized in Fig. 3. The decay of photoexcited state of $\mathbf{C}_{60} \subset \mathbf{H}_{4}-\mathbf{C}_{\mathbf{4}}-\mathbf{C P D}_{\mathbf{P y}}$ (TEO) has two steps: the first step has a lifetime of $18 \mathrm{ps}$, which corresponds to the disappearance of the

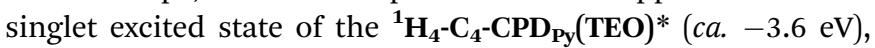
that is, the ${ }^{\mathbf{1}} \mathbf{H}_{\mathbf{4}}-\mathbf{C}_{\mathbf{4}}-\mathbf{C P D}_{\mathbf{P y}}(\mathbf{T E O}) *$ undergoes intrasupramolecular electron transfer to give a completely charge-separated state $\mathbf{C}_{60}{ }^{\cdot-}-\mathbf{H}_{4}-\mathbf{C}_{\mathbf{4}}-\mathbf{C P D}_{\mathbf{P y}}(\mathbf{T E O})^{\cdot+}(\mathrm{ca} . \quad-3.7 \mathrm{eV})$. The $\mathbf{C}_{60}{ }^{\cdot-}-\mathbf{H}_{4}-\mathbf{C}_{\mathbf{4}^{-}}$ $\mathbf{C P D}_{\mathbf{P y}}(\mathbf{T E O})^{\cdot+}$ decays with a lifetime of $470 \mathrm{ps}$ to the ground state. The decay of photoexcited state of $\mathbf{C}_{60} \subset \mathbf{H}_{\mathbf{4}}-\mathbf{P t z}$ -

Table 1 Optical, electrochemical data and $\mathrm{HOMO}$ and LUMO energy levels of $\mathrm{H}_{4}-\mathrm{C}_{4}-\mathrm{CPD}_{\mathrm{Py}}(\mathrm{TEO}), \mathrm{C}_{60} \subset \mathrm{H}_{4}-\mathrm{C}_{4}-\mathrm{CPD}_{\mathrm{Py}}\left(\mathrm{TEO}_{\mathrm{C}}\right) \mathrm{H}_{4}-\mathrm{Ptz}-$ $\mathrm{CPD}_{\mathrm{Py}}(\mathrm{TEO})$, and $\mathrm{C}_{60} \subset \mathrm{H}_{4}-\mathrm{Ptz}-\mathrm{CPD}_{\mathrm{Py}}(\mathrm{TEO})$

\begin{tabular}{|c|c|c|c|c|}
\hline Porphyrin dimers & $\lambda_{\max }^{\mathrm{abs}} / \mathrm{nm}\left(\varepsilon / \mathbf{M}^{-1} \mathrm{~cm}^{-1}\right)^{a}$ & $E_{\mathrm{pa}}^{\mathrm{oxb}} / \mathrm{V} v s . \mathrm{Fc} / \mathrm{Fc}^{+}$ & $\mathrm{HOMO}^{c} / \mathrm{eV}$ & $\mathrm{LUMO}^{c} / \mathrm{eV}$ \\
\hline $\mathrm{H}_{4}-\mathrm{C}_{4}-\mathrm{CPD}_{\mathrm{Py}}(\mathrm{TEO})$ & 422 (646 000), 517 (30 800), 551 (9800), 590 (9600), 647 (4300) & 0.71 & -5.51 & -3.61 \\
\hline $\mathrm{C}_{60} \subset \mathrm{H}_{4}-\mathrm{C}_{4}-\mathrm{CPD}_{\mathrm{Py}}(\mathrm{TEO})$ & - & 0.74 & -5.54 & -3.64 \\
\hline $\mathrm{C}_{60} \subset \mathrm{H}_{4}-$ Ptz-CPD $\mathrm{Py}_{\mathrm{Py}}(\mathrm{TEO})$ & - & 0.75 & -5.55 & -3.65 \\
\hline
\end{tabular}

${ }^{a}$ In benzonitrile. ${ }^{b}$ Anodic $\left(E_{\mathrm{pa}}\right)$ peak potentials for oxidation were recorded in benzonitrile $/ \mathrm{Bu}_{4} \mathrm{NPF}_{6}(0.1 \mathrm{M})$ solution for the porphyrin unit in $\mathbf{H}_{4}-\mathrm{C}_{4}{ }^{-}$

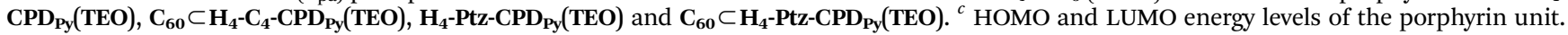



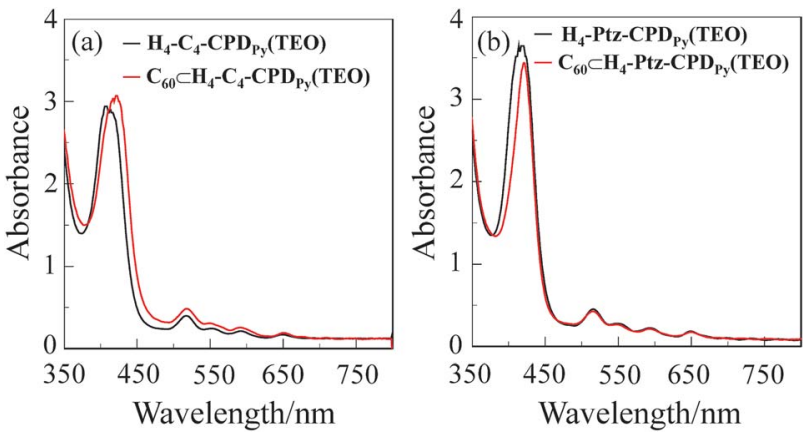

Fig. 2 UV/vis absorption spectra of (a) $\mathrm{H}_{4}-\mathrm{C}_{4}-\mathrm{CPD}_{\mathrm{Py}}(\mathrm{TEO})$ and $\mathrm{C}_{60} \subset \mathrm{H}_{4}-\mathrm{C}_{4}-\mathrm{CPD}_{\mathrm{Py}}(\mathrm{TEO})$ and (b) $\mathrm{H}_{4}-\mathrm{Ptz}^{-C P D_{\mathrm{Py}}}(\mathrm{TEO})$ and $\mathrm{C}_{60} \subset \mathrm{H}_{4}-$ Ptz-CPD ${ }_{\text {Py }}\left(\right.$ TEO) adsorbed on $\mathrm{TiO}_{2}$ film $(3 \mu \mathrm{m})$.

$\mathbf{C P D}_{\mathbf{P y}}(\mathbf{T E O})$ also includes the charge-separated states $\mathbf{C}_{\mathbf{6 0}}{ }^{\cdot-}-\mathbf{H}_{4}{ }^{-}$ Ptz-CPD $_{\mathbf{P y}}(\text { TEO })^{\cdot+}(\mathrm{ca} .-3.8 \mathrm{eV})$, but has multiple steps to the ground state via the triplet charge separated state ${ }^{3}\left(\mathbf{C}_{\mathbf{6 0}}{ }^{\cdot-}-\mathbf{H}_{\mathbf{4}^{-}}\right.$ $\mathbf{P t z}^{\cdot+}{ }^{-C_{P}} \mathbf{P D}_{\mathbf{P y}}$ (TEO) $(\mathrm{ca} .-4.3 \mathrm{eV})$ with a lifetime of $0.71 \mathrm{~ms}$ : the first step has a lifetime of $20 \mathrm{ps}$, which is similar to that (18 ps) of $\mathbf{C}_{60} \subset \mathbf{H}_{4}-\mathbf{C}_{4}-\mathbf{C P D}_{\mathbf{P y}}$ (TEO). On the other hand, the energy diagrams for the photochemical events in these porphyrin dimes revealed that the energy levels of charge-separated states is very close to or lower than the $E_{\mathrm{cb}}$ of the $\mathrm{CB}$ of $\mathrm{TiO}_{2}$ electrode. This suggests that the electron injection from the $\mathbf{C}_{60}{ }^{--}$in the charge-separated states to the $\mathrm{CB}$ of $\mathrm{TiO}_{2}$ electrode is thermodynamically difficult.

\section{FTIR spectra of cyclic free-base porphyrin dimers and their inclusion complexes with fullerene $\mathbf{C}_{60}$}

To elucidate the adsorption states of cyclic free-base porphyrin dimers and their $\mathrm{C}_{60}$ inclusion complexes on $\mathrm{TiO}_{2}$ nanoparticles, we measured the FTIR spectra of the porphyrin dimer powders and the porphyrin dimers adsorbed on $\mathrm{TiO}_{2}$ nanoparticles (Fig. 4). For the powders of all the four porphyrin

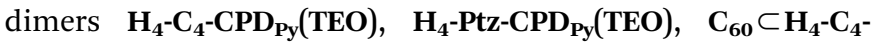
$\mathbf{C P D}_{\mathbf{P y}}(\mathbf{T E O})$, and $\mathbf{C}_{60} \subset \mathbf{H}_{4}-\mathbf{P t z}-\mathbf{C P D}_{\mathbf{P y}}(\mathbf{T E O})$, the $\mathrm{C}=\mathrm{N}$ stretching band of pyridyl group was clearly observed at around $1590 \mathrm{~cm}^{-1}$. Interestingly, when these porphyrin dimers were adsorbed on the $\mathrm{TiO}_{2}$ surface, a new band appeared at around $1650 \mathrm{~cm}^{-1}$, which indicates the formation of a pyridinium ion with Brønsted acid sites on $\mathrm{TiO}_{2}$ surface. ${ }^{21}$ In addition, the $\mathrm{C}=\mathrm{N}$

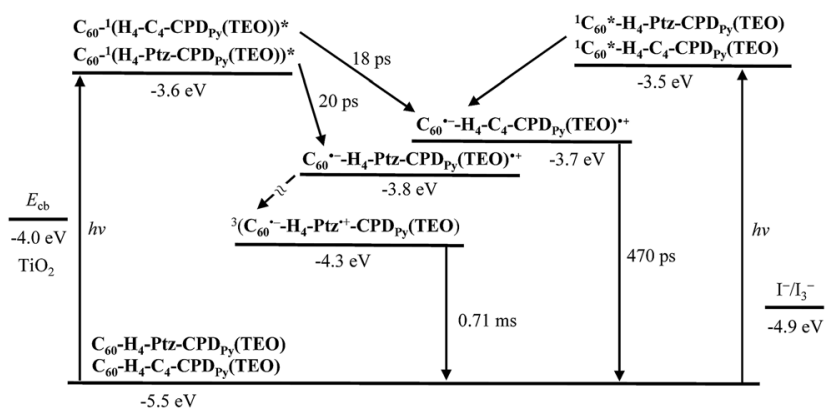

Fig. 3 Energy diagrams for the photochemical events in $\mathrm{C}_{60} \subset \mathrm{H}_{4}-\mathrm{C}_{4}$ $\mathrm{CPD}_{\mathrm{Py}}(\mathrm{TEO})$ and $\mathrm{C}_{60} \subset \mathrm{H}_{4}-\mathrm{Ptz}-\mathrm{CPD}_{\mathrm{Py}}(\mathrm{TEO})$.
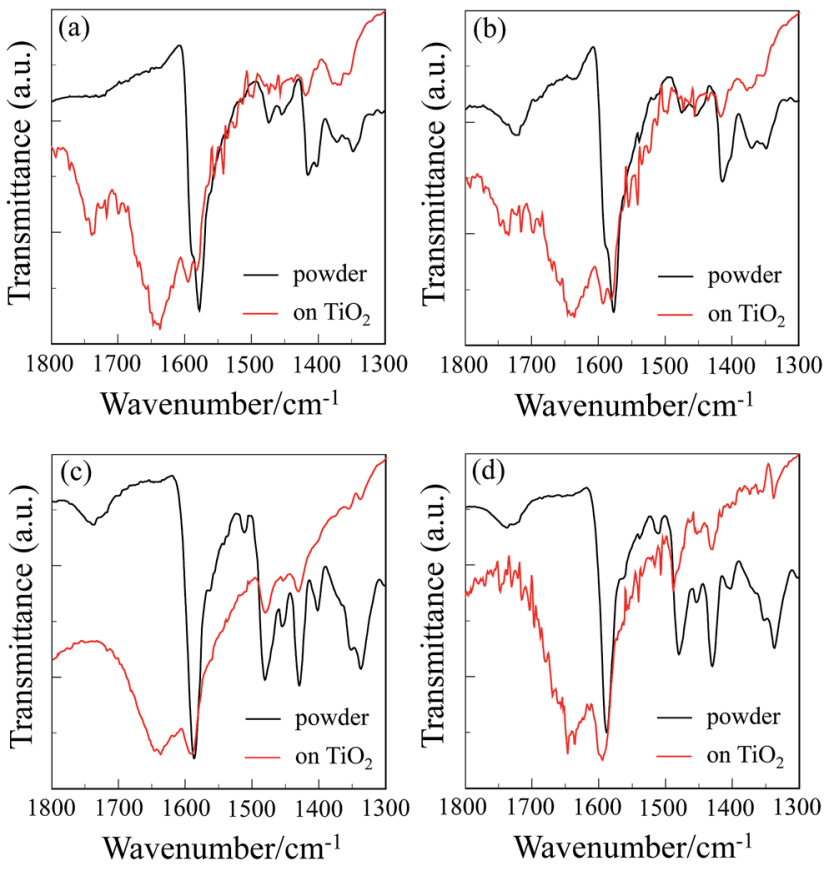

Fig. 4 FTIR spectra of the porphyrin dimer powders and the porphyrin dimers adsorbed on $\mathrm{TiO}_{2}$ nanoparticles for (a) $\mathrm{H}_{4}-\mathrm{C}_{4}-\mathrm{CPD}_{\mathrm{Py}}(\mathrm{TEO})$, (b) $\mathrm{C}_{60} \subset \mathrm{H}_{4}-\mathrm{C}_{4}-\mathrm{CPD}_{\mathrm{Py}}(\mathrm{TEO})$, (c) $\mathrm{H}_{4}-\mathrm{Ptz}-\mathrm{CPD}_{\mathrm{Py}}(\mathrm{TEO})$, and (d) $\mathrm{C}_{60} \subset \mathrm{H}_{4}-$ Ptz-CPD $D_{\mathrm{Py}}(\mathrm{TEO})$.

stretching band at around $1590 \mathrm{~cm}^{-1}$ is shifted by $3-5 \mathrm{~cm}^{-1}$ to higher wavenumber, that is, the resulting band can be assigned to the hydrogen-bonded pyridyl group to Brønsted acid sites on the $\mathrm{TiO}_{2}$ surface. Consequently, these observations demonstrate that these porphyrin dimers are adsorbed on the $\mathrm{TiO}_{2}$ surface through the formations of hydrogen bonding of pyridyl groups and/or pyridinium ion at Brønsted acid sites on the $\mathrm{TiO}_{2}$ surface. Thus, the UV/vis absorption and the FTIR spectra of the porphyrin dimers adsorbed on $\mathrm{TiO}_{2}$ film indicate that high dye loading and high surface coverage of the $\mathrm{TiO}_{2}$ electrode for DSSCs based on porphyrin dye sensitizers bearing pyridyl group are achieved by employing the cyclic porphyrin dimers bearing four pyridyl anchoring groups possessing the bonding ability to the two points on Brønsted acid sites on $\mathrm{TiO}_{2}$ surface.

Photovoltaic performances of DSSCs based on cyclic free-base porphyrin dimers and their inclusion complexes with fullerene $\mathbf{C}_{60}$

The DSSC was prepared using the dye-adsorbed $\mathrm{TiO}_{2}$ electrode (9 $\mu \mathrm{m})$, Pt-coated glass as a counter electrode, and an acetonitrile solution with iodine $(0.05 \mathrm{M})$, lithium iodide $(0.1 \mathrm{M})$, and 1,2-dimethyl-3-propylimidazolium iodide $(0.6 \mathrm{M})$ as an electrolyte. The photocurrent-voltage $(I-V)$ characteristics were measured under simulated solar light (AM 1.5, $100 \mathrm{~mW} \mathrm{~cm}^{-2}$ ). The incident photon-to-current conversion efficiency (IPCE) spectra and the $I-V$ curves are shown in Fig. 5. The photovoltaic performance parameters are collected in Table 2. The IPCE values corresponding to the Soret band (29\% at $424 \mathrm{~nm}$ ) and the $\mathrm{Q}$ band $(6 \%$ at $520 \mathrm{~nm}$ ) for the phenothiazine-bridged cyclic 
porphyrin dimer $\mathbf{H}_{\mathbf{4}}$-Ptz-CPD $\mathbf{P D y}_{\mathbf{P y}}$ (TEO) are higher than those (15\% at $420 \mathrm{~nm}$ for the Soret band and $2 \%$ at $522 \mathrm{~nm}$ for the Q band) of the butadiyne-linked cyclic porphyrin dimer $\mathbf{H}_{\mathbf{4}}-\mathbf{C}_{\mathbf{4}}-\mathbf{C P D}_{\mathbf{P y}}{ }^{-}$ (TEO) (Fig. 5a). The $I-V$ curves show that the short-circuit photocurrent density $\left(J_{\mathrm{sc}}\right)$ and $\eta$ values of $\mathbf{H}_{\mathbf{4}}$-Ptz-CPD $\mathbf{P y}$ (TEO) (1.40 $\mathrm{mA} \mathrm{cm}{ }^{-2}$ and $\left.0.35 \%\right)$ are higher than those of $\mathbf{H}_{4}-\mathbf{C}_{\mathbf{4}^{-}}$ CPD $_{\text {Py }}$ (TEO) (0.79 $\mathrm{mA} \mathrm{cm}^{-2}$ and 0.19\%) (Fig. 5b). The higher photovoltaic performance for DSSC based on $\mathbf{H}_{\mathbf{4}}-\mathbf{P t z}-\mathbf{C P D}_{\mathbf{P y}^{-}}$ (TEO) may be attributed to the efficient electron injection from the photoexcited dye $\left({ }^{\mathbf{1}} \mathbf{H}_{\mathbf{4}}\right.$-Ptz-CPD $\left.\mathbf{P y}(\mathbf{T E O})^{*}\right)$ to the $\mathrm{CB}$ of $\mathrm{TiO}_{2}$ electrode because the phenothiazine unit possessing electron donating ability can provide a unidirectional flow of electrons toward the pyridyl anchoring group upon photoexcitation of the porphyrin. Interestingly, the photovoltaic performances of DSSC based on the $\mathrm{C}_{60}$ inclusion complexes $\mathbf{C}_{60} \subset \mathbf{H}_{\mathbf{4}}-\mathbf{C}_{\mathbf{4}^{-}}$$\mathbf{C P D}_{\mathbf{P y}}$ (TEO) and $\mathbf{C}_{60} \subset \mathbf{H}_{\mathbf{4}}$-Ptz-CPD Py $_{\mathbf{P y}}$ (TEO) are lower than those of $\mathbf{H}_{\mathbf{4}}-\mathbf{C}_{\mathbf{4}}-\mathbf{C P D} \mathbf{P D}_{\mathbf{P y}}(\mathbf{T E O})$ and $\mathbf{H}_{\mathbf{4}}-\mathbf{P t z}-\mathbf{C P D}_{\mathbf{P y}}(\mathbf{T E O})$. The electron injection $(\approx 100 \mathrm{ps})$ from the photoexcited porphyrin to the $\mathrm{CB}$ of $\mathrm{TiO}_{2}$ electrode is in kinetically competition with the intrasupramolecular electron transfer $(18-20 \mathrm{ps})$, that is, the formation of charge-separated state $\mathbf{C}_{60}{ }^{--}-\mathbf{H}_{4}-\mathbf{C}_{\mathbf{4}}-\mathbf{C P D}_{\mathbf{P y}}(\mathbf{T E O})^{\cdot+}$ and $\mathbf{C}_{60}{ }^{\cdot-}$ - $_{4}$-Ptz-CPD Py (TEO) ${ }^{\cdot+}$ (Fig. 3). Therefore, the lower photovoltaic performances for DSSC based on the $\mathrm{C}_{60}$ inclusion complexes would be attributed to the formation of charge-separated state, leading to low electron-injection efficiency from the photoexcited porphyrin to $\mathrm{CB}$ of $\mathrm{TiO}_{2}$ electrode. On the other hand, the photovoltaic performance of DSSC based on $\mathbf{C}_{60} \subset \mathbf{H}_{\mathbf{4}}$-Ptz-CPD $\mathbf{P D}_{\mathbf{P y}}$ (TEO) is slightly lower than that of $\mathbf{C}_{60} \subset \mathbf{H}_{4}-\mathbf{C}_{4}-\mathbf{C P D}_{\mathbf{P y}}$ (TEO), which may be attributed to the thermodynamically difficult electron-injection due to the lower triplet charge separated state ${ }^{3}\left(\mathbf{C}_{\mathbf{6 0}}{ }^{-}{ }^{-}-\mathbf{H}_{\mathbf{4}}-\mathbf{P t z}^{\cdot+}\right.$. CPD $_{\mathbf{P y}}$ (TEO)).

Moreover, it is worth mentioning here that the open-circuit photovoltage $\left(V_{\mathrm{oc}}\right)$ values of the $\mathrm{C}_{60}$ inclusion complexes

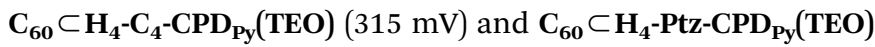
(304 $\mathrm{mV}$ ) are lower than those of $\mathbf{H}_{\mathbf{4}}-\mathbf{C}_{\mathbf{4}}$-CPD $\mathbf{\text { Py }}$ (TEO) $(376 \mathrm{mV}$ ) and $\mathbf{H}_{\mathbf{4}}$-Ptz-CPD $\mathbf{P y}$ (TEO) (396 mV). Thus, electrochemical impedance spectroscopy (EIS) analysis was performed to study the electron recombination process in DSSCs based on these porphyrin dimers in the dark under a forward bias of $-0.60 \mathrm{~V}$ with a frequency range of $10 \mathrm{mHz}$ to $100 \mathrm{kHz}$. The large
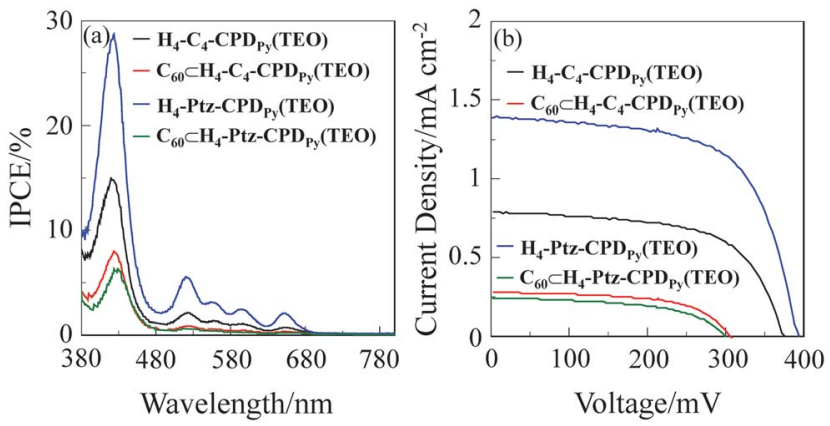

Fig. 5 (a) IPCE spectra and (b) I-V curves of DSSCs based on $\mathrm{H}_{4}-\mathrm{C}_{4}$ $\mathrm{CPD}_{\mathrm{Py}}(\mathrm{TEO}), \mathrm{C}_{60} \subset \mathrm{H}_{4}-\mathrm{C}_{4}-\mathrm{CPD}_{\mathrm{Py}}(\mathrm{TEO}), \mathrm{H}_{4}-\mathrm{Ptz}-\mathrm{CPD}_{\mathrm{Py}}(\mathrm{TEO})$, and $\mathrm{C}_{60} \subset \mathrm{H}_{4}-\mathrm{Ptz}-\mathrm{CPD}_{\mathrm{Py}}(\mathrm{TEO})$.
Table 2 DSSC performance parameters of $\mathrm{H}_{4}-\mathrm{C}_{4}-\mathrm{CPD}_{\mathrm{Py}}(\mathrm{TEO})$, $\mathrm{C}_{60} \subset \mathrm{H}_{4}-\mathrm{C}_{4}-\mathrm{CPD}_{\mathrm{Py}}(\mathrm{TEO}), \mathrm{H}_{4}-\mathrm{Ptz}-\mathrm{CPD}_{\mathrm{Py}}(\mathrm{TEO})$, and $\mathrm{C}_{60} \subset \mathrm{H}_{4}-\mathrm{Ptz}-$ $\mathrm{CPD}_{\mathrm{Py}}(\mathrm{TEO})$

\begin{tabular}{|c|c|c|c|c|}
\hline Porphyrin dimers ${ }^{a}$ & $J_{\mathrm{sc}} / \mathrm{mA} \mathrm{cm}^{-2 b}$ & $V_{\mathrm{oc}}{ }^{b} / \mathrm{mV}$ & $\mathrm{ff}^{b}$ & $\eta^{b}(\%)$ \\
\hline $\mathrm{H}_{4}-\mathrm{C}_{4}-\mathrm{CPD}_{\mathrm{Py}}(\mathrm{TEO})$ & 0.79 & 376 & 0.64 & 0.19 \\
\hline $\mathrm{C}_{60} \subset \mathrm{H}_{4}-\mathrm{C}_{4}-\mathrm{CPD}_{\mathrm{Py}}(\mathrm{TEO})$ & 0.27 & 315 & 0.69 & 0.06 \\
\hline $\mathrm{H}_{4}-\mathrm{Ptz}_{-}-\mathrm{CPD}_{\mathrm{Py}}(\mathrm{TEO})$ & 1.40 & 396 & 0.63 & 0.35 \\
\hline $\mathrm{C}_{60} \subset \mathrm{H}_{4}-$-Ptz-CPD ${ }_{\mathrm{Py}}$ (TEO) & 0.24 & 304 & 0.54 & 0.04 \\
\hline
\end{tabular}

${ }^{a}$ The adsorption amount of the porphyrin dimers adsorbed on $\mathrm{TiO}_{2}$ electrode is $2.0 \times 10^{17}$ molecules per $\mathrm{cm}^{2}$ under the adsorption condition of $0.1 \mathrm{mM}$ porphyrin dimer solution in chloroform. The amount of adsorbed dye on $\mathrm{TiO}_{2}$ electrode was determined form the calibration curve by absorption spectral measurement of the concentration change of the dye solution before and after adsorption. ${ }^{b}$ Under a simulated solar light (AM 1.5, $100 \mathrm{~mW} \mathrm{~cm}^{-2}$ ).

semicircle in the Nyquist plot (Fig. 6a), which corresponds to the midfrequency peaks in the Bode phase plots, represents the charge recombination between the injected electrons in $\mathrm{TiO}_{2}$ and $\mathrm{I}_{3}{ }^{-}$ions in the electrolyte, that is, the charge-transfer resistances at the $\mathrm{TiO}_{2} /$ dye/electrolyte interface. The Nyquist plots show that the resistance values of the large semicircle for $\mathbf{H}_{\mathbf{4}}-\mathbf{C}_{\mathbf{4}}$-CPD Pyy $_{\text {(TEO) }}(13 \Omega)$ and $\mathbf{H}_{\mathbf{4}}$-Ptz-CPD $\mathbf{P y}$ (TEO) $(14 \Omega)$ are higher than those of $\mathbf{C}_{60} \subset \mathbf{H}_{4}-\mathbf{C}_{4}$ - $\mathbf{C P D}_{\mathbf{P y}}$ (TEO) $(5 \Omega)$ and $\mathbf{C}_{60} \subset \mathbf{H}_{4}$ Ptz-CPD $_{\mathbf{P y}}$ (TEO) (5 $\Omega$ ), indicating that the electron recombination resistances for $\mathbf{H}_{4}-\mathbf{C}_{\mathbf{4}}-\mathbf{C P D}_{\mathbf{P y}}$ (TEO) and $\mathbf{H}_{\mathbf{4}}-\mathbf{P t z}-\mathbf{C P D}_{\mathbf{P y}}$ (TEO) are larger those of $\mathbf{C}_{60} \subset \mathbf{H}_{4}-\mathbf{C}_{\mathbf{4}}$-CPD $\mathbf{P y}\left(\right.$ TEO) and $\mathbf{C}_{60} \subset \mathbf{H}_{\mathbf{4}}$-Ptz$\mathbf{C P D}_{\mathbf{P y}}(\mathbf{T E O})$. The electron recombination lifetimes $\left(\tau_{\mathrm{e}}\right)$ expressing the electron recombination between the injected electrons in $\mathrm{TiO}_{2}$ and $\mathrm{I}_{3}{ }^{-}$ions in the electrolyte, extracted from the angular frequency $\left(\omega_{\text {rec }}\right)$ at the midfrequency peak in the Bode phase plot (Fig. 6b) using $\tau_{\mathrm{e}}=1 / \omega_{\text {rec }}$, increase in the order of $\mathbf{C}_{60} \subset \mathbf{H}_{4}-\mathbf{C}_{4}-\mathbf{C P D}_{\mathbf{P y}}$ (TEO) $(0.1 \mathrm{~ms})$ and $\mathbf{C}_{60} \subset \mathbf{H}_{\mathbf{4}}$-Ptz-CPD $\mathbf{P y}^{-}$ (TEO) $(0.1 \mathrm{~ms})<\mathbf{H}_{4}-\mathbf{C}_{\mathbf{4}}$-CPD Py (TEO) $(2.2 \mathrm{~ms})<\mathbf{H}_{\mathbf{4}}$-Ptz-CPD Py $^{-}$ (TEO) $(2.5 \mathrm{~ms})$, respectively, which are consistent with the sequence of $V_{\mathrm{oc}}$ values in the DSSCs. Consequently, this is attributed to the fact that the formation of charge-separated state $\mathbf{C}_{60}{ }^{\cdot-}{ }^{-} \mathbf{H}_{4}-\mathbf{C}_{4}-\mathbf{C P D}_{\mathbf{P y}}(\mathbf{T E O})^{\cdot+}$ and $\mathbf{C}_{60}{ }^{\cdot-}-\mathbf{H}_{4}-$ Ptz-CPD $_{\mathrm{Py}}(\mathbf{T E O})^{\cdot+}$ facilitates the approach of $\mathrm{I}_{3}{ }^{-}$ions to the $\mathrm{TiO}_{2}$ surface because of complexation between the charge-separated state and $\mathrm{I}_{3}{ }^{-}$
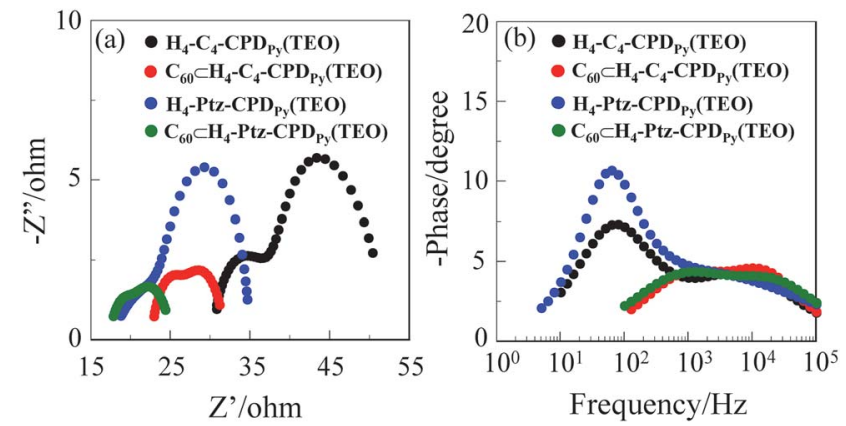

Fig. 6 (a) Nyquist plots and (b) Bode phase plots of DSSCs based on $\mathrm{H}_{4}-\mathrm{C}_{4}-\mathrm{CPD}_{\mathrm{Py}}(\mathrm{TEO}), \mathrm{C}_{60} \subset \mathrm{H}_{4}-\mathrm{C}_{4}-\mathrm{CPD}_{\mathrm{Py}}(T E O), \mathrm{H}_{4}-\mathrm{Ptz}^{-C P D_{\mathrm{Py}}}(\mathrm{TEO})$, and $\mathrm{C}_{60} \subset \mathrm{H}_{4}-\mathrm{Ptz}-\mathrm{CPD}_{\mathrm{Py}}(\mathrm{TEO})$. 
ions, leading to faster charge recombination and thus resulting in a lower $V_{\text {oc }}$ value.,

\section{Conclusions}

In this work, to seek a direction in molecular design toward creating a new class of porphyrin dye sensitizers bearing pyridyl anchoring groups for achieving high dye loading and high surface coverage of the $\mathrm{TiO}_{2}$ electrode for dye-sensitized solar cells (DSSCs), cyclic free-base porphyrin dimers $\left(\mathbf{H}_{\mathbf{4}}-\mathbf{C}_{\mathbf{4}}-\mathbf{C P D}_{\mathbf{P y}^{-}}\right.$ (TEO) and $\mathbf{H}_{\mathbf{4}}$-Ptz-CPD $\mathbf{P y}$ (TEO)) linked by butadiyne or phenothiazine bearing 4-pyridyl groups and their $\mathrm{C}_{60}$ inclusion complexes $\left(\mathbf{C}_{60} \subset \mathbf{H}_{4}-\mathbf{C}_{4}-\mathbf{C P D}_{\mathbf{P y}}\right.$ (TEO) and $\mathbf{C}_{60} \subset \mathbf{H}_{\mathbf{4}}$-Ptz-CPD $\mathbf{P y}^{-}$ (TEO)) have been applied to DSSCs as the dye sensitizers. The Soret bands of $\mathbf{C}_{60} \subset \mathbf{H}_{4}-\mathbf{C}_{\mathbf{4}}-\mathbf{C P D}_{\mathbf{P y}}$ (TEO) and $\mathbf{C}_{60} \subset \mathbf{H}_{4}$-PtzCPD $_{\mathbf{P y}}$ (TEO) were redshifted with a decrease in intensity, whereas their $\mathrm{Q}$ bands were slightly redshifted but increased in intensity, compared to $\mathbf{H}_{\mathbf{4}}-\mathbf{C}_{\mathbf{4}}-\mathbf{C P D}_{\mathbf{P y}}$ (TEO) and $\mathbf{H}_{\mathbf{4}}$-Ptz-CPD $\mathbf{P y}^{-}$ (TEO). These porphyrin dimers are adsorbed on the $\mathrm{TiO}_{2}$ surface through the formations of hydrogen bonding of pyridyl groups and/or pyridinium ion at Brønsted acid sites on the $\mathrm{TiO}_{2}$ surface. It was found that the adsorption amount of the porphyrin dimers adsorbed on $\mathrm{TiO}_{2}$ film is $2.0 \times 10^{17}$ molecules per $\mathrm{cm}^{2}$, that is, the adsorption amount of porphyrin unit is $4.0 \times 10^{17} \mathrm{~cm}^{-2}$, which is higher than those $\left(<2.0 \times 10^{17}\right.$ molecules per $\mathrm{cm}^{2}$ ) of porphyrin dye sensitizers and $\mathrm{D}-\pi-\mathrm{A}$ dye sensitizer bearing pyridyl groups reported so far. The higher photovoltaic performance for DSSC based on $\mathbf{H}_{\mathbf{4}}-\mathbf{P t z}-\mathbf{C P D}_{\mathbf{P y}^{-}}$ (TEO) relative to $\mathbf{H}_{\mathbf{4}}-\mathbf{C}_{\mathbf{4}}-\mathbf{C P D}_{\mathbf{P y}}$ (TEO) may be attributed to the efficient electron injection from the photoexcited dye $\left({ }^{1} \mathbf{H}_{\mathbf{4}} \mathbf{- P t z}-\right.$ CPD ${ }_{\mathbf{P y}}\left(\right.$ TEO) ${ }^{*}$ ) to the $\mathrm{CB}$ of $\mathrm{TiO}_{2}$ because the phenothiazine unit possessing electron donating ability can provide a unidirectional flow of electrons toward the pyridyl anchoring group upon photoexcitation of the porphyrin. On the other hand, the photovoltaic performances of DSSC based on $\mathbf{C}_{60} \subset \mathbf{H}_{4}-\mathbf{C}_{4^{-}}$

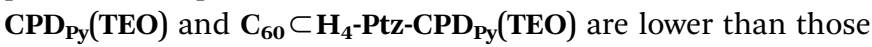
of $\mathbf{H}_{\mathbf{4}}-\mathbf{C}_{\mathbf{4}}-\mathbf{C P D}_{\mathbf{P y}}(\mathrm{TEO})$ and $\mathbf{H}_{\mathbf{4}}-\mathbf{P t z}-\mathbf{C P D}_{\mathbf{P y}}(\mathrm{TEO})$. The transient absorption spectroscopy and electrochemical measurements revealed that the lower photovoltaic performances for DSSC based on the $\mathrm{C}_{60}$ inclusion complexes would be attributed to the formation of charge-separated state between the photoexcited porphyrin and $\mathrm{C}_{60}$, leading to low electron-injection efficiency from the photoexcited porphyrin to $\mathrm{TiO}_{2}$ electrode. Consequently, this work provides that the cyclic porphyrin dimers with four pyridyl anchoring groups possessing bonding ability to the two points on Brønsted acid sites on $\mathrm{TiO}_{2}$ surface, which can achieve the high dye loading and the high surface coverage of the $\mathrm{TiO}_{2}$ electrode, would be expected to be one of the most promising classes of porphyrin dye sensitizers with pyridyl group.

\section{Experimental}

General

Infrared (IR) absorption spectra were recorded on a Perkin Elmer Spectrum One FT-IR spectrometer by ATR method and a Bio-Rad FTS6000 spectrometer by $\mathrm{KBr}$ disk method. Ultraviolet/visible (UV/vis) absorption spectra were observed with Shimadzu UV-3150 and UV-2500PC spectrophotometers. Nuclear magnetic resonance (NMR) spectra were recorded on a Bruker AVANCE III 600 spectrometer. The resonance frequencies are $600 \mathrm{MHz}$ for ${ }^{1} \mathrm{H}$ and $151 \mathrm{MHz}$ for ${ }^{13} \mathrm{C}$. Chemical shifts were reported as $\delta$ values in ppm relative to tetramethylsilane. High-resolution fast atom bombardment mass spectra (HR-FAB-MS) were measured with 3-nitrobenzyl alcohol (NBA) as a matrix and recorded on a JEOL LMS-HX-110 spectrometer. Melting point (Mp) measurements were carried out on a Yanaco MP-S3 melting point meter. Cyclic voltammetry (CV) and differential pulse voltammetry (DPV) were carried out on an ALS630C (BAS, Japan) electrochemical analyzer in deaerated benzonitrile containing $0.1 \mathrm{M}$ tetra- $n$-butylammonium hexafluorophosphate $\left(\mathrm{Bu}_{4} \mathrm{NPF}_{6}\right)$ as a supporting electrolyte at room temperature under an Ar atmosphere. A conventional threeelectrode cell was used with a platinum working electrode (surface area of $0.3 \mathrm{~mm}^{2}$ ) and a platinum wire as a counter electrode. The measured potentials were recorded with respect to an $\mathrm{Ag} / \mathrm{AgNO}_{3}(0.01 \mathrm{M})$ reference electrode. All potentials ( $v s$. $\mathrm{Ag}^{+} / \mathrm{Ag}$ ) were converted to values with respect to that of the $\mathrm{Fc}^{+} /$ Fc redox couple, which was measured under the same conditions. The highest occupied molecular orbital (HOMO) and lowest unoccupied molecular orbital (LUMO) energy levels of porphyrin dimers were evaluated from the spectral analyses and the DPV data. The HOMO energy level was evaluated from the oxidation wave for porphyrin dimers. The LUMO energy level was estimated from the singlet excited energy of these porphyrin dimers $(1.90 \mathrm{eV})$ based on the $\mathrm{Q}$ absorption band $\mathrm{nm}$ and fluorescence band in benzonitrile.

\section{Synthesis}

5,15-Bis $\{3-[2-(2-e t h o x y e t h o x y)$ ethoxy]-5-[(trimethylsilyl)ethynyl]phenyl\}-10,20-di\{4-pyridyl\}porphine (1). A solution of 3-[2-(2ethoxyethoxy)ethoxy]-5-[(trimethylsilyl)ethynyl] benz-aldehyde ${ }^{22}$ (4.63 g, $13.8 \mathrm{mmol}$ ) and meso-(4-pyridyl)-dipyrromethane ${ }^{23}$ $(3.08 \mathrm{~g}, 13.9 \mathrm{mmol})$ in $\mathrm{CH}_{2} \mathrm{Cl}_{2}(1.4 \mathrm{~L})$ was degassed with a stream of $\mathrm{N}_{2}$ for $30 \mathrm{~min}$. To this solution, trifluoroacetic acid (TFA) $(12.3 \mathrm{~mL}, 166 \mathrm{mmol})$ was added and stirred under a $\mathrm{N}_{2}$ atmosphere. After $30 \mathrm{~min}$, the resultant mixture was neutralized with $\mathrm{NEt}_{3}$ (23 mL, $0.17 \mathrm{~mol}$ ) and then 2,3-dichloro-5,6-dicyano-1,4benzoquinone (DDQ) $(4.7 \mathrm{~g}, 21 \mathrm{mmol})$ dissolved in benzene $(250 \mathrm{~mL})$ was added to the mixture. After an overnight stirring, the resultant mixture was purified by column chromatography (silica-gel, $\mathrm{CHCl}_{3} / \mathrm{EtOH}=50 / 1$ ) then recrystallized from $\mathrm{CHCl}_{3} /$ $i$-PrOH to give 1 as a purple solid $(1.27 \mathrm{~g}, 18 \%) .{ }^{1} \mathrm{H} \mathrm{NMR}\left(\mathrm{CDCl}_{3}\right.$, $600 \mathrm{MHz}$ ): $\delta-2.91$ (br-s, 2H, -NH), $0.27\left(\mathrm{~s}, 18 \mathrm{H},-\mathrm{Si}\left(\mathrm{CH}_{3}\right)_{3}\right), 1.18$ $\left(\mathrm{t}, J=7.2 \mathrm{~Hz}, 6 \mathrm{H},-\mathrm{O}\left(\mathrm{CH}_{2} \mathrm{CH}_{2} \mathrm{O}\right)_{2} \mathrm{CH}_{2} \mathrm{CH}_{3}\right), 3.52(\mathrm{q}, J=7.2 \mathrm{~Hz}$, $\left.4 \mathrm{H},-\mathrm{O}\left(\mathrm{CH}_{2} \mathrm{CH}_{2} \mathrm{O}\right)_{2} \mathrm{CH}_{2} \mathrm{CH}_{3}\right), 3.63(\mathrm{dd}, J=4.8$ and $6.0 \mathrm{~Hz}, 4 \mathrm{H}$, $\left.-\mathrm{O}\left(\mathrm{CH}_{2}\right)_{2} \mathrm{OCH}_{2} \mathrm{CH}_{2} \mathrm{OC}_{2} \mathrm{H}_{5}\right), 3.76\left(\mathrm{t}, J=4.8 \mathrm{~Hz}, 4 \mathrm{H},-\mathrm{O}\left(\mathrm{CH}_{2}\right)_{2}-\right.$ $\left.\mathrm{OCH}_{2} \mathrm{CH}_{2} \mathrm{OC}_{2} \mathrm{H}_{5}\right), 3.96\left(\mathrm{t}, J=4.8 \mathrm{~Hz}, 4 \mathrm{H},-\mathrm{OCH}_{2} \mathrm{CH}_{2} \mathrm{O}\left(\mathrm{CH}_{2}\right)_{2}-\right.$ $\left.\mathrm{OC}_{2} \mathrm{H}_{5}\right), 4.36\left(\mathrm{t}, J=4.8 \mathrm{~Hz}, 4 \mathrm{H},-\mathrm{OCH}_{2} \mathrm{CH}_{2} \mathrm{O}\left(\mathrm{CH}_{2}\right) \mathrm{OC}_{2} \mathrm{H}_{5}\right), 7.47$ (br-s, 2H, Ar-H), 7.75 (br-s, 2H, Ar-H), 7.93 (br-s, 2H. Ar-H), 8.17 $(\mathrm{d}, J=5.4 \mathrm{~Hz}, 4 \mathrm{H}, \mathrm{Ar}-\mathrm{H}), 8.81(\mathrm{~d}, J=4.2 \mathrm{~Hz}, 4 \mathrm{H}$, pyrrole $\beta-\mathrm{H})$, $8.92(\mathrm{~d}, J=4.8 \mathrm{~Hz}, 4 \mathrm{H}$, pyrrole $\beta-\mathrm{H}), 9.06(\mathrm{~d}, J=6.0 \mathrm{~Hz}, 4 \mathrm{H}, \mathrm{Ar}-$ $\mathrm{H}) ;{ }^{13} \mathrm{C} \mathrm{NMR}\left(\mathrm{CDCl}_{3}, 151 \mathrm{MHz}\right): \delta 0.1,15.3,66.9,68.1,69.9,70.0$, 71.2, 94.7, 104.9, 117.2, 117.4, 119.7, 122.6, 122.6, 129.6, 131.1, 
143.1, 148.5, 150.3, 157.2; HR-FAB-MS (NBA): $\mathrm{m} / z$ calcd for $\mathrm{C}_{64} \mathrm{H}_{68} \mathrm{~N}_{6} \mathrm{O}_{6} \mathrm{Si}_{2}$ : 1072.4739; found: 1072.4718; UV/vis $\left(\mathrm{CHCl}_{3}\right)$ : $\lambda_{\max }\left(\varepsilon, \mathrm{cm}^{-1} \mathrm{M}^{-1}\right) 421$ (392 000), 515 (18 200), 549 (5400), 588 (5400), 645 (2100); IR (KBr): $\nu=3439,3317,3092,3022,2956$, 2928, 2867, 2714, 2614, 2533, 2156, 1591, 1582, 1476, 1420, 1404, 352, 1323, 1297, 1247, 1196, 1173, 1161, 1114, 1069, 976, 927, 847, 800, 788, 760, 730, 697, 660, 563, $411 \mathrm{~cm}^{-1}$; Mp: $>300{ }^{\circ} \mathrm{C}$.

\{5,15-Di\{3-[2-(2-ethoxyethoxy)ethoxy]-5-ethynyl]phenyl\}-10,20di\{4-pyridyl\}porphinato\}zinc(II) (2). $\mathrm{Zn}(\mathrm{OAc})_{2} \cdot 2 \mathrm{H}_{2} \mathrm{O} \quad(2.4 \mathrm{~g}$, $11 \mathrm{mmol})$ dissolved in $\mathrm{MeOH}(60 \mathrm{~mL})$ was added to a solution of $1(1.16 \mathrm{~g}, 1.08 \mathrm{mmol})$ in $\mathrm{CH}_{2} \mathrm{Cl}_{2}(1.1 \mathrm{~L})$. The resultant mixture was refluxed overnight under $\mathrm{N}_{2}$ atmosphere and then cooled to room temperature. The reaction mixture was neutralized with saturated aqueous solution of $\mathrm{NaHCO}_{3}(200 \mathrm{~mL})$, washed with water ( $200 \mathrm{~mL}, 2$ times), dried over $\mathrm{Na}_{2} \mathrm{SO}_{4}$ and evaporated. The residue and $\mathrm{KF} \cdot 2 \mathrm{H}_{2} \mathrm{O}(0.63 \mathrm{~g}, 6.7 \mathrm{mmol})$ were dissolved in DMF (40 $\mathrm{mL}$ ) and the mixture was stirred overnight under a $\mathrm{N}_{2}$ atmosphere. After the stirring, the resultant mixture was diluted with $\mathrm{CHCl}_{3}(100 \mathrm{~mL})$ and washed with water $(500 \mathrm{~mL}, 2$ times). The organic layer was dried over $\mathrm{Na}_{2} \mathrm{SO}_{4}$ and evaporated to give the product as a purple solid $(1.00 \mathrm{~g}, 99 \%) .{ }^{1} \mathrm{H}$ NMR (pyridine- $d_{5}$, $600 \mathrm{MHz}): \delta 1.00\left(\mathrm{t}, J=7.2 \mathrm{~Hz}, 6 \mathrm{H},-\mathrm{O}\left(\mathrm{CH}_{2} \mathrm{CH}_{2} \mathrm{O}\right)_{2} \mathrm{CH}_{2} \mathrm{CH}_{3}\right), 3.33$ $\left(\mathrm{q}, J=6.6 \mathrm{~Hz}, 4 \mathrm{H},-\mathrm{O}\left(\mathrm{CH}_{2} \mathrm{CH}_{2} \mathrm{O}\right)_{2} \mathrm{CH}_{2} \mathrm{CH}_{3}\right), 3.52(\mathrm{t}, J=4.8 \mathrm{~Hz}$, $\left.4 \mathrm{H},-\mathrm{O}\left(\mathrm{CH}_{2}\right)_{2} \mathrm{OCH}_{2} \mathrm{CH}_{2} \mathrm{OC}_{2} \mathrm{H}_{5}\right), 3.67(\mathrm{t}, J=4.8 \mathrm{~Hz}, 4 \mathrm{H}$, $\left.-\mathrm{O}\left(\mathrm{CH}_{2}\right)_{2} \mathrm{OCH}_{2} \mathrm{CH}_{2} \mathrm{OC}_{2} \mathrm{H}_{5}\right), 3.87\left(\mathrm{t}, \mathrm{J}=4.8 \mathrm{~Hz}, 4 \mathrm{H},-\mathrm{OCH}_{2} \mathrm{CH}_{2}-\right.$ $\left.\mathrm{O}\left(\mathrm{CH}_{2}\right)_{2} \mathrm{OC}_{2} \mathrm{H}_{5}\right), 4.15(\mathrm{~s}, 2 \mathrm{H},-\mathrm{C} \equiv \mathrm{CH}) 4.31(\mathrm{t}, J=4.8 \mathrm{~Hz}, 4 \mathrm{H}$, $\left.-\mathrm{OCH}_{2} \mathrm{CH}_{2} \mathrm{O}\left(\mathrm{CH}_{2}\right) \mathrm{OC}_{2} \mathrm{H}_{5}\right), 7.68$ (d, $\left.J=0.6 \mathrm{~Hz}, 2 \mathrm{H}, \mathrm{Ar}-\mathrm{H}\right), 8.05$ (br-s, 2H, Ar-H), 8.23 (d, J=4.2 Hz, $2 \mathrm{H}, \mathrm{Ar}-\mathrm{H}), 8.26$ (d, J=4.2 Hz, $4 \mathrm{H}, \mathrm{Ar}-\mathrm{H}), 9.02(\mathrm{~d}, J=4.8 \mathrm{~Hz}, 4 \mathrm{H}$, pyrrole $\beta-\mathrm{H}), 9.11(\mathrm{~d}, J=$ $5.4 \mathrm{~Hz}, 4 \mathrm{H}, \mathrm{Ar}-\mathrm{H}), 9.15$ (d, $J=4.8 \mathrm{~Hz}, 4 \mathrm{H}$, pyrrole $\beta-\mathrm{H}) ;{ }^{13} \mathrm{C}$ NMR (pyridine- $d_{5}, 151 \mathrm{MHz}$ ): $\delta 15.5,66.5,68.5,70.0,70.3,71.2,79.6$, 84.5, 117.6, 118.7, 120.6, 122.0, 130.1, 131.7, 132.2, 132.9, 145.2, 148.7, 149.8, 150.3, 150.7, 151.4, 157.7; HR-FAB-MS (NBA): $\mathrm{m} / \mathrm{z}$ calcd for $\mathrm{C}_{58} \mathrm{H}_{50} \mathrm{~N}_{6} \mathrm{O}_{6} \mathrm{Zn}$ : 990.3083; found: 990.3082; UV/vis $\left(\mathrm{CHCl}_{3}\right): \lambda_{\max }\left(\varepsilon, \mathrm{cm}^{-1} \mathrm{M}^{-1}\right) 425$ (418 000), 555 (16 200), 595 (2400); IR (KBr): $\nu=3433,3283,2972,2928,2872,1592,1581$, 1540, 1523, 1488, 1456, 1419, 1344, 1321, 1298, 1283, 1246, 1204, 1181, 1113, 1071, 1048, 998, 938, 874, 819, 796, 763, 719, 675, 665, 569, 545, 436, $419 \mathrm{~cm}^{-1}$; Mp: $>300{ }^{\circ} \mathrm{C}$.

$\mathbf{H}_{4}-\mathbf{C}_{\mathbf{4}}-\mathbf{C P D}_{\mathbf{P y}}(\mathbf{T E O})$. The free-base dimer was prepared from 2 (397 $\mathrm{mg}, 0.4 \mathrm{mmol})$ with $\mathrm{CuCl}(8.0 \mathrm{~g}, 80 \mathrm{mmol})$ in pyridine $(1.2 \mathrm{~L})$ according to the reported procedure. ${ }^{20 a, d}$ The crude product was purified by flash column chromatography (silicagel, $\mathrm{CHCl}_{3} / \mathrm{EtOH}=100 / 1$ to $10 / 1$ ) and recrystallized from $\mathrm{CHCl}_{3} / i$-PrOH to give the product as a purple powder $(48 \mathrm{mg}$, 13\%). ${ }^{1} \mathrm{H}$ NMR $\left(\mathrm{CDCl}_{3}, 600 \mathrm{MHz}\right): \delta-3.04$ (br-s, $\left.4 \mathrm{H},-\mathrm{NH}\right), 1.21$ $\left(\mathrm{t}, J=7.2 \mathrm{~Hz}, 12 \mathrm{H},-\mathrm{O}\left(\mathrm{CH}_{2} \mathrm{CH}_{2} \mathrm{O}\right)_{2} \mathrm{CH}_{2} \mathrm{CH}_{3}\right), 3.55(\mathrm{q}, J=7.2 \mathrm{~Hz}$, $\left.8 \mathrm{H},-\mathrm{O}\left(\mathrm{CH}_{2} \mathrm{CH}_{2} \mathrm{O}\right)_{2} \mathrm{CH}_{2} \mathrm{CH}_{3}\right), 3.67$ (dd, $J=4.8$ and $6.0 \mathrm{~Hz}, 8 \mathrm{H}$, $\left.-\mathrm{O}\left(\mathrm{CH}_{2}\right)_{2} \mathrm{OCH}_{2} \underline{\mathrm{C}}_{2} \mathrm{OC}_{2} \mathrm{H}_{5}\right), 3.81$ (dd, $J=4.8$ and $6.0 \mathrm{~Hz}, 8 \mathrm{H}$, $\left.-\mathrm{O}\left(\mathrm{CH}_{2}\right)_{2} \mathrm{OCH}_{2} \mathrm{CH}_{2} \mathrm{OC}_{2} \mathrm{H}_{5}\right), 4.03\left(\mathrm{t}, \mathrm{J}=4.8 \mathrm{~Hz}, 8 \mathrm{H},-\mathrm{OCH}_{2} \mathrm{CH}_{2}-\right.$ $\left.\mathrm{O}\left(\mathrm{CH}_{2}\right)_{2} \mathrm{OC}_{2} \mathrm{H}_{5}\right), 4.42\left(\mathrm{t}, J=4.8 \mathrm{~Hz}, 8 \mathrm{H},-\mathrm{OC}_{2} \mathrm{CH}_{2} \mathrm{O}\left(\mathrm{CH}_{2}\right)\right.$ $\left.\mathrm{OC}_{2} \mathrm{H}_{5}\right), 6.88(\mathrm{~s}, 4 \mathrm{H}, \mathrm{Ar}-\mathrm{H}), 7.25(\mathrm{dd}, J=0.6$ and $1.8 \mathrm{~Hz}, 4 \mathrm{H}, \mathrm{Ar}-$ $\mathrm{H}), 7.94$ (br-s, 8H, Ar-H), 8.22 (t, $J=1.8 \mathrm{~Hz}, 4 \mathrm{H}, \mathrm{Ar}-\mathrm{H}), 8.62$ (d, $J=4.2 \mathrm{~Hz}, 8 \mathrm{H}$, pyrrole $\beta-\mathrm{H}), 8.70(\mathrm{~d}, J=4.2 \mathrm{~Hz}, 8 \mathrm{H}$, pyrrole $\beta-$ $\mathrm{H}), 8.96$ (br-s, 8H, Ar-H); ${ }^{13} \mathrm{C} \mathrm{NMR}\left(\mathrm{CDCl}_{3}, 151 \mathrm{MHz}\right): \delta 15.3$, 66.9, 68.3, 70.0, 70.1, 71.3, 74.5, 83.1, 114.9, 117.1, 118.6, 120.4, $120.8,129.3,135.3,143.0,148.4,149.9,157.8$; HR-FAB-MS
(NBA): $m / z$ calcd for $\mathrm{C}_{116} \mathrm{H}_{100} \mathrm{~N}_{12} \mathrm{O}_{12}$ : 1852.7584; found: 1852.7545; UV/vis (PhCN): $\lambda_{\max }\left(\varepsilon, \mathrm{cm}^{-1} \mathrm{M}^{-1}\right) ; 422$ (646 000), 517 (30 800), 551 (9800), 590 (9600), 647 (4300); IR (ATR): $\nu=3312$, 2971, 2920, 2865, 1578, 1474, 1455, 1415, 1372, 1348, 1285, 1254, 1221, 1195, 1172, 1108, 1062, 993, 974, 930, 871, 849, 797, 728, 692, 659, 563, 540, 517, 467, $411 \mathrm{~cm}^{-1}$; Mp: $>300{ }^{\circ} \mathrm{C}$.

\section{Preparation of DSSCs}

The $\mathrm{TiO}_{2}$ paste (JGC Catalysts and Chemicals Ltd., PST-18NR) was deposited on a fluorine-doped-tin-oxide (FTO) substrate by doctor-blading, and sintered for $50 \mathrm{~min}$ at $450{ }^{\circ} \mathrm{C}$. The $9 \mu \mathrm{m}$ thick $\mathrm{TiO}_{2}$ electrode was immersed into $0.1 \mathrm{mM}$ porphyrin dimer solution in chloroform for 15 hours enough to adsorb the dye sensitizers. The DSSCs were fabricated by using the $\mathrm{TiO}_{2}$ electrode $\left(0.5 \times 0.5 \mathrm{~cm}^{2}\right.$ in photoactive area) thus prepared, Pt-coated glass as a counter electrode, and a solution of $0.05 \mathrm{M}$ iodine, 0.1 M lithium iodide, and $0.6 \mathrm{M}$ 1,2-dimethyl-3propylimidazolium iodide in acetonitrile as electrolyte. The photocurrent-voltage characteristics were measured using a potentiostat under a simulated solar light (AM 1.5, 100 $\mathrm{mW} \mathrm{cm}^{-2}$ ). IPCE spectra were measured under monochromatic irradiation with a tungsten-halogen lamp and a monochromator. The amount of adsorbed dye on $\mathrm{TiO}_{2}$ nanoparticles was determined form the calibration curve by absorption spectral measurement of the concentration change of the porphyrin dye solution before and after adsorption. Absorption spectra of the dyes adsorbed on $\mathrm{TiO}_{2}$ nanoparticles were recorded on the porphyrin dyes-adsorbed $\mathrm{TiO}_{2}$ film (thickness of $3 \mu \mathrm{m}$ ) in the transmission mode with a calibrated integrating sphere system. Electrochemical impedance spectroscopy (EIS) for DSSCs in the dark under a forward bias of $-0.60 \mathrm{~V}$ with a frequency range of $10 \mathrm{mHz}$ to $100 \mathrm{kHz}$ was measured with a AMETEK Versa STAT 3.

\section{Acknowledgements}

This work was supported by Grants-in-Aid (No. 20108009 and 15K05432 to F. T. and No. $15 \mathrm{H} 03859$ to Y. O.) from Ministry of Education, Culture, Sports, Science and Technology of Japan and Research Grants to F. T. from Tokuyama Science and Technology Foundation and Iketani Science and Technology Foundation.

\section{Notes and references}

1 B. O'Regan and M. Grätzel, Nature, 1991, 353, 737.

2 A. Hagfeldt, G. Boschloo, L. Sun, L. Kloo and H. Pettersson, Chem. Rev., 2010, 110, 6595.

3 (a) Z. Ning and H. Tian, Chem. Commun., 2009, 5483; (b) Z. Ning, Y. Fu and H. Tian, Energy Environ. Sci., 2010, 3, 1170.

4 A. Mishra, M. K. R. Fischer and P. Bäuerle, Angew. Chem., Int. Ed., 2009, 48, 2474.

5 Y. Ooyama and Y. Harima, Eur. J. Org. Chem., 2009, 18, 2903. 6 Y. Ooyama and Y. Harima, ChemPhysChem, 2012, 13, 4032.

7 N. Manfredi, B. Cecconi and A. Abbotto, Eur. J. Org. Chem., 2014, 7069. 
8 (a) X. Wang, J. Yang, H. Yu, F. Li, L. Fan, W. Sun, Y. Liu, Z. Y. Koh, J. Pan, W.-L. Yim, L. Yan and Q. Wang, Chem. Commun., 2014, 50, 3965; (b) S.-G. Li, K.-J. Jiang, J.-H. Huang, L.-M. Yang and Y.-L. Song, Chem. Commun., 2014, 50, 4309; (c) D. K. Panda, F. S. Goodson, S. Ray and S. Saha, Chem. Commun., 2014, 50, 5358; (d) K. Kakiage, Y. Aoyama, T. Yano, T. Otsuka, T. Kyomen, M. Unno and M. Hanaya, Chem. Commun., 2014, 50, 6379; (e) A. Amacher, C. Yi, J. yang, M. P. Bircher, Y. Fu, M. Cascella, M. Grätzel, S. Decurtins and S.-X. Liu, Chem. Commun., 2014, 50, 6540; ( $f$ ) J. Yang, P. Ganesan, J. Teuscher, T. Moehl, Y. J. Kim, C. Yi, P. Comte, K. Pei, T. W. Holcombe, M. K. Nazeeruddin, J. Hua, S. K. Zakeeruddin, H. Tian and M. Grätzel, J. Am. Chem. Soc., 2014, 136, 5772.

9 (a) T. Ikeuchi, H. Nomoto, N. Masaki, M. J. Griffith, S. Mori and M. Kimura, Chem. Commun., 2014, 50, 1941; (b) R. Agosta, R. Grisorio, L. De Marco, G. Romanazzi, G. P. Suranna, G. Gigli and M. Manca, Chem. Commun., 2014, 50, 9451; (c) A. Dessi, M. Calamante, A. Mordini, M. Peruzzin, A. Sinicropi, R. Basosi, F. F. de Biani, M. Taddei, D. Colonna, A. D. Carlo, G. Reginato and L. Zani, Chem. Commun., 2014, 50, 13952; (d) X. Sun, Y. Wang, X. Li, H. Ågren, W. Zhu, H. Tian and Y. Xie, Chem. Commun., 2014, 50, 15609.

10 (a) H. Imahori, T. Umeyama and S. Ito, Acc. Chem. Res., 2009, 42, 1809; (b) S. Eu, S. Hayashi, T. Umeyama, Y. Matano, Y. Araki and H. Imahori, J. Phys. Chem. C, 2008, 112, 4396; (c) A. Kira, Y. Matsubara, H. Iijima, T. Umeyama, Y. Matano, S. Ito, M. Niemi, N. V. Tkachenko, H. Lemmetyinen and H. Imahori, J. Phys. Chem. C, 2010, 114, 11293; (d) H. Imahori, H. Iijima, H. Hayashi, Y. Toude, T. Umeyama, Y. Matano and S. Ito, ChemSusChem, 2011, 4, 797; (e) K. Kurotobi, Y. Toude, K. Kawamoto, Y. Fujimori, S. Ito, P. Chabera, V. Sundström and H. Imahori, Chem.-Eur. J., 2013, 19, 17075; (f) T. Higashino and H. Imahori, Dalton Trans., 2015, 44, 448.

11 (a) T. Bessho, S. M. Zakeeruddin, C.-Y. Yeh, E. W.-G. Diau and M. Grätzel, Angew. Chem., Int. Ed., 2010, 49, 6646; (b) A. Yella, H.-W. Lee, H. N. Tsao, C. Yi, A. K. Chandiran, M. K. Nazeeruddin, E. W.-G. Diau, C.-Y. Yeh, S. M. Zakeeruddin and M. Grätzel, Science, 2011, 334, 629; (c) L.-L. Li and E. W.-G. Diau, Chem. Soc. Rev., 2013, 42, 291; (d) S. Mathew, A. Yella, P. Gao, R. Humphry-Baker, B. F. E. Curchod, N. Ashari-Astani, I. Tavernelli, U. Rothlisberger, M. K. Nazeeruddin and M. Grätzel, Nat. Chem., 2014, 6, 242; (e) A. Yella, C.-L. Mai, S. M. Zakeeruddin, S.-N. Chang, C.-H. Hsieh, C.-Y. Yeh and M. Grätzel, Angew. Chem., Int. Ed., 2014, 53, 2973.

12 (a) M. V. Martínez-Díaz, G. de la Torre and T. Torres, Chem. Commun., 2010, 46, 7090; (b) M. J. Griffith, K. Sunahara, P. Wagner, K. Wagner, G. G. Wallace, D. L. Officer, A. Furube, R. Katoh, S. Mori and A. J. Mozer, Chem. Commun., 2012, 48, 4145; (c) K. Ladomenou, T. N. Kitsopoulos, G. D. Sharma and A. G. Coutsolelos, RSC Adv. , 2014, 4, 21379.
13 (a) Y.-C. Chang, C.-L. Wang, T.-Y. Pan, S.-H. Hong, C.-M. Lan, H.-H. Kuo, C.-F. Lo, H.-Y. Hsu, C.-Y. Lin and E. W.-G. Diau, Chem. Commun., 2011, 47, 8910; (b) M. Ishida, D. Hwang, Y. B. Koo, J. Sung, D. Y. Kim, J. L. Sessler and D. Kim, Chem. Commun., 2013, 49, 9164; (c) C. Lo, S. Hsu, C. Wang, Y. Cheng, H. Lu, E. W. Diau and C. Lin, J. Phys. Chem. C, 2010, 114, 12018; (d) J. Lu, X. Xu, K. Cao, J. Cui, Y. Zhang, Y. Shen, X. Shi, L. Liao, Y. Cheng and M. Wang, J. Mater. Chem. A, 2013, 1, 10008; (e) R. B. Ambre, G.-F. Chang, M. R. Zanwar, C.-F. Yao, E. W.-G. Diau and C.-H. Hung, Chem.-Asian J., 2013, 8, 2144; (f) R. B. Ambre, G.-F. Chang and C.-H. Hung, Chem. Commun., 2014, 50, 725.

14 (a) C.-L. Wang, Y.-C. Chang, C.-M. Lan, C.-F. Lo, E. WeiGuang Diau and C.-Y. Lin, Energy Environ. Sci., 2011, 4, 1788; (b) C.-H. Wu, T.-Y. Pan, S.-H. Hong, C.-L. Wang, H.-H. Kuo, Y.-Y. Chu, E. W.-G. Diau and C.-Y. Lin, Chem. Commun., 2012, 48, 4329; (c) H.-P. Lu, C.-L. Mai, C.-Y. Tsia, S.-J. Hsu, C.-P. Hsieh, C.-L. Chiu, C.-Y. Yeh and E. W.-G. Diau, Phys. Chem. Chem. Phys., 2009, 11, 10270; (d) C.-H. Wu, M.-C. Chen, P.-C. Su, H.-H. Kuo, C.-L. Wang, C.-Y. Lu, C.-H. Tsai, C.-C. Wu and C.-Y. Lin, J. Mater. Chem. A, 2014, 2, 991; (e) J. M. Ball, N. K. S. Davis, J. D. Wilkinson, J. Kirkpatrick, J. Teuscher, R. Gunning, H. L. Anderson and H. J. Snaith, RSC Adv., 2012, 2, 6846; (f) C.-L. Mai, W.-K. Huang, H.-P. Lu, C.-W. Lee, C.-L. Chiu, Y.-R. Liang, E. W.-G. Diau and C.-Y. Yeh, Chem. Commun., 2010, 46, 809.

15 (a) K. Sunahara, M. J. Griffith, T. Uchiyama, P. Wagner, D. L. Officer, G. G. Wallace, A. J. Mozer and S. Mori, ACS Appl. Mater. Interfaces, 2013, 5, 10824; (b) T. Hamamura, J. T. Dy, K. Tamaki, J. Nakazaki, S. Uchida, T. Kubo and H. Segawa, Phys. Chem. Chem. Phys., 2014, 16, 4551; (c) H.-P. Wu, Z.-W. Ou, T.-Y. Pan, C.-M. Lan, W.-K. Huang, H.-W. Lee, N. M. Reddy, C.-T. Chen, W.-S. Chao, C.-Y. Yeh and E. W.-G. Diau, Energy Environ. Sci., 2012, 5, 9843; (d) C.-L. Wang, J.-Y. Hu, C.-H. Wu, H.-H. Kuo, Y.-C. Chang, Z.-J. Lan, H.-P. Wu, E. Wei-Guang Diau and C.-Y. Lin, Energy Environ. Sci., 2014, 7, 1392; (e) J. Luo, M. Xu, R. Li, K.-W. Huang, C. Jiang, Q. Qi, W. Zeng, J. Zhang, C. Chi, P. Wang and J. Wu, J. Am. Chem. Soc., 2014, 136, 265.

16 (a) Y. Ooyama, S. Inoue, R. Asada, G. Ito, K. Kushimoto, K. Komaguchi, I. Imae and Y. Harima, Eur. J. Org. Chem., 2010, 92; (b) Y. Ooyama, S. Inoue, T. Nagano, K. Kushimoto, J. Ohshita, I. Imae, K. Komaguchi and Y. Harima, Angew. Chem., Int. Ed., 2011, 50, 7429; (c) Y. Ooyama, T. Nagano, S. Inoue, I. Imae, K. Komaguchi, J. Ohshita and Y. Harima, Chem.-Eur. J., 2011, 17, 14837; (d) Y. Ooyama, N. Yamaguchi, I. Imae, K. Komaguchi, J. Ohshita and Y. Harima, Chem. Commun., 2013, 49, 2548; (e) Y. Ooyama, Y. Hagiwara, T. Mizumo, Y. Harima and J. Ohshita, New J. Chem., 2013, 37, 2479; (f) Y. Ooyama, T. Sato, Y. Harima and J. Ohshita, J. Mater. Chem. A, 2014, 2, 3293.

17 (a) Y. Harima, T. Fujita, Y. Kano, I. Imae, K. Komaguchi, Y. Ooyama and J. Ohshita, J. Phys. Chem. C, 2013, 117, 16364; (b) N. Shibayama, H. Ozawa, M. Abe, Y. Ooyama and H. Arakawa, Chem. Commun., 2014, 50, 6398. 
18 (a) J. Lu, X. Xu, Z. Li, k. Cao, J. Cui, Y. Zhang, Y. Shen, Y. Li, J. Zhu, S. Dai, W. Chjen, Y. Cheng and M. Wang, Chem.-Asian J., 2013, 8, 956; (b) T. Sakurada, Y. Arai and H. Segawa, RSC Adv., 2014, 4, 13201; (c) D. Daphnomili, G. Landrou, P. Singh, A. Thomas, K. Yesudas, B. K. G. D. Sharma and A. G. Goutsolelos, RSC Adv., 2012, 2, 12899; (d) D. Daphnomili, G. D. Sharma, S. Biswas, T. K. R. Justin and A. G. Goutsolelos, J. Photochem. Photobiol., A, 2013, 253, 88; (e) C. Stangel, A. Bagaki, P. A. Angaridis, G. Charalambidis, G. D. Sharma and A. G. Coutsolelos, Inorg. Chem., 2014, 53, 11871.

19 (a) M.-D. Zhang, H.-X. Xie, X.-H. Ju, L. Qin, Q.-X. Yang, H.-G. Zheng and X.-F. Zhou, Phys. Chem. Chem. Phys., 2013, 15, 634; (b) L. Wang, X. yang, S. Li, M. Cheng and L. Sun, $R S C A d v$., 2013, 3, 13677; (c) J. Mao, D. Wang, S.-H. Liu, Y. Hang, Y. Xu, Q. Zhang, W. Wu, P.-T. Chou and J. Hua, Asian J. Org. Chem., 2014, 3, 153; (d) J. Massin, L. Ducasse, T. Toupance and C. Olivier, J. Phys. Chem. C, 2014, 118, 10677; (e) L. Zhang, J. M. Cole and C. Dai, ACS Appl. Mater. Interfaces, 2014, 6, 7535.

20 (a) H. Nobukuni, Y. Shimazaki, H. Uno, Y. Naruta, K. Okubo, T. Kojima, S. Fukuzumi, S. Seki, H. Sakai, T. Hasobe and
F. Tani, Chem.-Eur. J., 2010, 16, 11611; (b) H. Nobukuni, T. Kamimura, H. Uno, Y. Shimazaki, Y. Naruta and F. Tani, Bull. Chem. Soc. Jpn., 2012, 85, 862; (c) K. Sakaguchi, T. Kamimura, H. Uno, S. Mori, S. Ozako, H. Nobukuni, M. Ishida and F. Tani, J. Org. Chem., 2014, 79, 2980; (d) T. Kamimura, K. Ohkubo, Y. Kawashima, H. Nobukuni, Y. Naruta, F. Tani and S. Fukuzumi, Chem. Sci., 2013, 4, 1451; (e) T. Kamimura, K. Ohkubo, Y. Kawashima, S. Ozako, K. Sakaguchi, S. Fukuzumi and F. Tani, J. Phys. Chem. C, 2015, 119, 25634.

21 (a) T. J. Dines, L. D. MacGregor and C. H. Rochester, Phys. Chem. Chem. Phys., 2001, 3, 2676; (b) M. I. Zaki, M. A. Hasan, F. A. Al-Sagheer and L. Pasupulety, Colloids Surf., A, 2001, 190, 261; (c) O. Kasende and T. ZeegersHuyskens, J. Phys. Chem., 1984, 88, 2132; (d) H. Takahashi, K. Mamola and E. K. Plyler, J. Mol. Spectrosc., 1966, 21, 217; (e) M. A. Montańez, I. L. Tocón, J. C. Otero and J. I. Marcos, J. Mol. Struct., 1999, 482-483, 201.

22 T. Kamimura, M. Komura, H. Komiyama, T. Iyoda and F. Tani, Chem. Commun., 2015, 51, 1685.

23 C. Ruzié, L. Michaudet and B. Boitrel, Tetrahedron Lett., 2002, 43, 7423. 